\title{
Active Experiencing in Postdramatic Performance: Affective Memory and Quarantine Theatre's Wallflower
}

Dr Tracy Crossley

Directorate of Performance, University of Salford, Manchester,

School of Arts and Media, New Adelphi Building, Salford, M5 4WT.

Tel: 01612957151

Email: t.l.crossley@salford.ac.uk

Postdramatic approaches to performance and Stanislavsky's methodology seemingly occupy divergent performance traditions. Nonetheless, both traditions often require performers to mine their own lives (albeit to different ends) and operate in an experiential realm that demands responsiveness to and within the live moment of performing. It is this realm that I explore in this paper, through an analysis of Quarantine Theatre's Wallflower (2015). I argue that Wallflower represents an example of postdramatic practice that blends a poetics of failure with a psychophysical dramaturgical approach that can be aligned with Stanislavsky's concepts of Affective Memory and Active Analysis. I also adopt Carnicke's use of the term 'active experiencing' to describe Wallflower's dramaturgical process. I argue that Wallflower provides a useful case study of practice that challenges the binary opposition between dramatic and postdramatic that is still prevalent in theatre and performance studies scholarship, and suggest that the application of aspects of Stanislavsky's System, nuanced by cognitive neuroscience, can expand the theorization of postdramatic theatre, which in turn generates techniques that can prove valuable in the rehearsal of dramatic theatre itself.

Tracy is a Senior Lecturer in Theatre and Performance at the University of Salford, Manchester, where she has taught for 17 years. She has been substantially involved in programme design, developing courses in Contemporary Theatre Practice and Drama and Theatre. She is currently developing a practical handbook for Making Postdramatic Theatre with Digital Theatre Plus.

Keywords: Stanislavsky; emotion; failure; dramaturgy; affect; flow

\section{Word count 8,604}




\section{Post/dramatic}

This paper is inspired by a performance of Quarantine Theatre's current touring production Wallflower, which I first attended at HOME, Manchester in 2015; a piece described on the company's website as 'a dance marathon' in which the performers are challenged to remember 'every dance they've ever danced'. ${ }^{1}$ What interested me about this piece is that, although its dramaturgy aligns with postdramatic theatre paradigms, it also involves processes that can be closely compared to Stanislavskian methodology, albeit without any recourse to characterization or mimetic representation. Yet it has been common in Performance Studies scholarship to regard Stanislavski’s System as synonymous with psychological realism. This is logical given the historical association between the development of the System and the reign of Naturalism, along with Stanislavski's close work with Chekhov. However, in recent years champions of Stanislavski's work have pointed to or re-evaluated his relevance for theatre in the twenty first century. For instance both Sharon Carnicke and Bella Merlin, in respective publications, have suggested that the System has value in relation to a range of forms beyond psychological realism, ${ }^{2}$ whilst Graham Stephenson (2012), suggests the system is applicable, not only to forms within the dramatic tradition but to postdramatic theatre also. ${ }^{3}$ Similarly Yana Meerzon has recently demonstrated correspondences between Stanislavski's System and the practice of the Wooster Group. ${ }^{4}$ Yes this is a rare exception. As Stephenson asserts, 'Stanislavski and the System have often been ignored as (presumably) obsolete and irrelevant - as their absence from many books on postmodern or postdramatic theatre attest. ${ }^{5}$

Of course the System does not lead obviously beyond the dramatic paradigm, since Stanislavski worked out and theorised his praxis within its terms and according to a 
Humanist ideology. In this respect, the System generally carries with it the ideological baggage of a logocentric theatrical tradition, to which postdramatic theatre is generally posited against. ${ }^{6}$ Within the terms of Hans-Thies Lehmann's postdramatic theory drama is, by its very nature logocentric, due to its subordination to the 'primacy of text' and construction of a totalising 'fictive cosmos' in which 'wholeness, illusion and world representation are inherent'. ${ }^{7}$ Lehmann theorizes postdramatic theatre, conversely, through an emphasis on the liveness of the theatre event, where the liveness becomes a material of it rather than an element that is effaced or suppressed by the fictional 'textcosmos'. Thus he emphasises 'the dimension of the time 'shared' by the performers and the audience as a processuality that is on principle open'. ${ }^{8}$ Yet he also acknowledges that the postdramatic cannot fully escape the representational apparatus when he distinguishes it from live art on the basis of the process of repetition inimical to all theatre production (whereas live art aims to realize unique moments), and in his concession that postdramatic "does not mean a theatre that exists "beyond" drama, without any relation to it'. ${ }^{9}$

Some scholars writing on postdramatic theatre have followed suit by acknowledging the inescapable presence of dramatic and representational elements within postdramatic practice. ${ }^{10}$ Nevertheless, in Acts and Apparitions (2013), Liz Tomlin has convincingly identified an 'existing and prevalent philosophical and ideological binary of a conservative, logocentric dramatic versus a radical, poststructuralist postdramatic' within scholarship on postdramatic theatre, which she finds problematic. ${ }^{11}$ As she writes,

With notable exceptions, the dramatic/postdramatic binary is thus consistently upheld on the perceived distinction between the 'illusion of the 'present tense' of dramatic fiction where the 'there and then' poses as the 'here and now' and the emphasis within 'non-representational' or 'presentational' postdramatic practice on the present time of the actual event, its liveness, its direct relationship to the audience in time and space. ${ }^{12}$ 
Tomlin deconstructs this binary through the lens of Derridean poststructuralism to show how some postdramatic works can also be considered to contain the spectre of logocentrism and how some forms of drama resist logocentric reinscription. I am not concerned with analysing disruptions or inscriptions of logocentrism in postdramatic theatre, in this paper. However I echo Tomlin's assertion that this binary is a false one, which is often inscribed to support claims as to the radicalism or innovation of the postdramatic as if postdramatic work has no efficacy otherwise. Beginning from this premise it seems credible to consider the value of applying Stanislavski's System to postdramatic theatre work, alongside theory associated with the postdramatic. I particularly engage with his concepts of affective memory and "experiencing", reframing these concepts through the lens of cognitive neuroscience, which, according to McConachie, can help us find "common ground between "theatre" and "performance", as they are usually defined' and 'may help to heal our institutional divisions' ${ }^{13}$ By analysising Quarantine's Wallflower within the framework, my aim, then, is to explore how a dialogue between the dramatic and the postdramatic can expand the theorization of the postdramatic and elucidate some of the processes in the making and experiencing of such work - both for performers and spectators.

\section{Emotion and Affectivity in Postdramatic Theatre}

Distinctions made between dramatic and postdramatic theatre are often aligned with a distinction between acting and performance. In place of character-based acting, postdramatic theatre more commonly adopts the playing of personae or task-based strategies, which performers enact as "performer-selves", and often without the projection of emotion that is central to dramatic acting as Michael Kirby argued in his

seminal paper from 1972: 'Acting and Not-Acting'. ${ }^{14}$ Here Kirby proposed a continuum 
from the emotionally invested 'complex acting' of dramatic theatrical forms to the more dispassionate, functional 'not acting' of task-based 'non-matrixed' performances. Although he associates not-acting with performance art rather than theatre per se, he was writing before the advent of the postdramatic, which often crosses into the realm of performance art and shares many of its sensibilities. Kirby also includes the somewhat murkier category of 'simple acting', which might involve 'a psychic or emotional component' and which, along with 'not acting', can be manifested in postdramatic theatre. ${ }^{15}$ Kirby's model is now somewhat outdated given the diversity of theatre and performance forms in the twenty first century, including the growth of "reality theatre". It is also limited because he only considers emotion in relation to fiction - in so far as it is acted or 'feigned' - and does not consider the broader affective relations with audiences within the duration of the performance event.

When considering this material dimension in relation to the postdramatic, Lehmann draws on Lyotard's notion of an 'energetic theatre', elaborating that it is 'a theatre not of meaning but of 'forces, intensities, present affects' ${ }^{16}$ He therefore implicitly highlights the putting into play of the live experiential dimension within postdramatic theatre as a potential aspect of its dramaturgy. Similarly Sarah Jane Bailes (2011) notes that postdramatic theatre engenders 'intensities and mood states' rather than emotions that 'service the development of character and linear plot'. ${ }^{17}$ I'll develop this later, for now it is suffice to note that the affective dimension has only recently begun to be explored in postdramatic theatre. ${ }^{18}$ This is perhaps because, a common approach in a large body of theatre work that can be described as postdramatic has been a tendency for irony as a substitute for emotion - from the work of pioneers like Forced Entertainment and the Wooster Group to more recently formed companies, such as Gob 
Squad and Made in China. Irony introduces a self-conscious reflexivity into the act of performing, which, following the Brechtian tradition of distanciation rather than Stanislavskian immersion, is usually associated with a self-reflexive deconstruction of familiar narrative and representational forms, to draw attention to the performance situation as a performance and/or explore the performativity of identity through citational aesthetics. In Dramatic theatre self-consciousness is usually considered as signaling a lack of skill or technique as it disrupts the illusion of the fictive world and embodied character. On the other hand, in many examples of postdramatic theatre an apparent, or performed, lack of skill is an approach that is often appropriated precisely to 'derail stage conventions [and] the ambitions of dramatic integrity' and challenge 'conventional standards of virtuosity. ${ }^{, 19}$ Bailes has termed this approach 'a poetics of failure' in the sense that it links both to the adoption of failure as performance strategy and, dramaturgically, to poststructuralist critiques of logocentric grand narratives (the "failure" of representation itself). Bailes outlines a taxonomy of failure that includes, as a performance mode, 'stuttering, stumbling, bumbling, bungling ... unconvincing acting, coping (or not), awkwardness, and inability' and, in dramaturgical composition, 'the use of chance, real-time tasks, endurance and repetition' as well as 'the incorporation of process, accidents and mistakes on stage', which create 'structural vulnerability' ${ }^{20}$ In a general sense, signs of failure in postdramatic performances function as markers of authenticity that either signal the presence of the performer alongside a role or performed representation and/or disrupt the mechanisms of representation through the break down of performance structures.

The poetics of failure is now firmly established in postdramatic theatre as a deconstructive strategy, but has also earned some criticism in recent academic writing. 
Tomlin, for instance, suggests it has become somewhat of a derivative cliché: 'the new mark of artistic sophistication and success' with its own prescriptive rules. ${ }^{21}$ Appropriated derivatively as a performance style, "failure" has perhaps no more effect than signifying its own activity of self-reflexivity, as Tomlin suggests. She gives one example of the now familiar convention of 'offering the illusion that the piece is unrehearsed, and that the performers are inadequately constructing the show in the space and time of the performance'. ${ }^{22}$ Through this kind of appropriation 'failure' becomes a represented act, albeit within a poststructuralist framework. This is not to suggest that such an approach lacks legitimacy or efficacy but rather that in such instances the dramaturgical framework is not open to the materiality of the theatre event and/or the shared experience with the audience in any essentially different way to a dramatic theatre piece. On the other hand, where the possibility of failure remains open through dramaturgical strategies, such as those identified by Baile, failure can operate in generative ways that enable genuinely authentic encounters between performers and spectators, as well as disrupt the power economies of the theatre as a representational apparatus.

I cite Tomlin's example because it relates quite closely to the dramaturgical composition of Quarantine's Wallflower, which can in many ways be classified according to Bailes's taxonomy of failure. However, this piece is (largely) constructed in the duration of the performance (performed in both ninety minute and five hour versions) rather than giving the illusion of such and thus consists of unrehearsed material (alongside some rehearsed material, which I discuss later). Therefore, we might say that in that challenge it sets its performers - of remembering, every dance they've ever danced - Wallflower begins from a premise of failure, which is also built into its 
dramaturgical framework. The memories and accompanying dances that form Wallflower's content are newly recalled in the performance event and performed as they are recalled (over 1,000 dances have been archived at the time of writing) and so each performance is unique, in part, because there is no fixed script or score.

\section{Wallflower}

My analysis here is shaped through a triangulation of my experience as a spectator at the event and the experiences of the Director, Richard Gregory, and performer James Monaghan. All quotations from Gregory and Monaghan are recorded verbatim from interviews conducted in February 2016 unless cited to other sources. ${ }^{23}$

Wallflower's performance space consists of a dance floor with seating on three sides and a wooden wall on the fourth. When the audience enters the space the piece has already begun and we watch three performers taking turns to remember and perform dances, or fragments of dances, from their personal history, as they also describe and narrate the situations, encounters and events associated with them. When not on stage the performers sit amongst the audience, who are occasionally addressed collectively or individually during the performance. Another performer, seated amongst the audience, functions as an archivist, recording all the dances in writing as a part of an archive that grows with every performance and each new dance, whilst "DJ" Greg Akehurst plays music or song recordings from a laptop to accompany the dances (sometimes requested by the performers, other times unprompted).

When taking their turn on stage to perform the performers use sense memory to try to recall details about a particular dance and the circumstances surrounding it: what song 
was playing or, failing that, what the mood of the music was; who they were with; what the environment was like; how they remember feeling at that time. Each performer's memories are triggered by the dances or stories of fellow performers in a kind of feedback loop. As Monaghan described it:

We'd get up when we could remember something and that was often triggered by something someone had done before, by association almost. Someone does a physical act, they speak; it could be anything. It could just be the fact that it was silent for a second and you think "oh yeah I remember this silent dance" and you stand up and you do one.

As many of the memories are either new ones, or recalled differently in each performance, the overall content of any specific performance is partly based on 'chance' occurrence, arising from the performers' responses to each other and coloured with their own general emotional state on that particular performance day. This lends the piece the kind of 'structural vunerability' that Bailes refers to. As Gregory reflected in our interview, 'it can be extraordinarily powerful or really boring, or it can be an abject failure'. Indeed, at the performance I attended, my experience in the early moments of the performance was one of slight irritation and disappointment. As the performers began to articulate their memories and re-enact the dances connected to them, their manner was hesitant and their physicality was awkward in way that I took to be deliberately self-conscious and which I initially perceived as an adopted and clichéd use of a poetics of failure as a performance style. However, as the performance progressed, changes started to happen that began to alter this perception; at times the performers appeared to become more immersed in and affected by their memories in a way that was not initially apparent. As this occurred I came to realise that what I had initially perceived as a performed act of remembering was actually a process of psychophysical recall, or affective memory: a process that is largely confined to the rehearsal process in dramatic theatre, but here is an essential part of Wallflower's composition. Whilst I'm 
not suggesting that Stanislavski's affective memory was used as a deliberate concept or technique in the making of Wallflower, I'm suggesting that it can be closely compared to the process used by Quarantine in the development of its dramaturgy.

\section{From Affective Memory to Active Experiencing}

As well documented, affective memory is the technique whereby an actor attempts to recall past experiences and revive associated feelings that may be analogous to the circumstances and events experienced by a character in a fictional role. Up to the late twentieth Century the standard understanding of this concept in Western acting was coloured by Strasberg's adoption of affective memory as a discrete concept that became the cornerstone of the American Method and by early Russian translations of his work, which helped create the impressions that this technique was later abandoned by Stanislavski and superseded by his development of the method of physical actions. ${ }^{24}$ Therefore affective memory became associated with an approach that was cerebral, internally-focused and self indulgent, with the method of physical actions positioned as a kind of corrective that focused instead on the actor's body and physical actions in space. ${ }^{25}$ However more recent translations of Stanislavski's writing by Jean Benedetti and scholarship by Carnicke and Merlin, among others, have challenged this binary understanding, demonstrating how Stanislavski's praxis was approached, even in its early articulations, as a psychophysical process: that is, a process 'where body and psychology (brain, emotions and imagination) were mutually dependent' and within which affective memory was conceived as part of a broader integrated system, rather than a discrete concept. ${ }^{26}$ 
The overarching aim of affective memory is to create an emotional connection between the actor's 'self' and role that will enable the actor to create a life-like and emotionally authentic performance. Yet, as Merlin points out, one of the difficulties in the use of affective memory for the development of a fictional character is that memories are subjective and unique to the individual's own experiences. Further, memories are not static phenomena and our perception of experiences and events can alter through recollection. By extension the emotions connected to particular memories can change, whereas an actor will need to repeat his or her performance many times. ${ }^{27}$ In fact it can be argued that the more a particular memory is used the more its affectivity diminishes so that a memory that might prove useful to an actor's performance on one occasion might not do subsequently. Moreover, emotions are connected to the body and subject to the mechanisms of the unconscious. As Merlin puts it, 'Who's to say that an actor will even be able to locate at will an appropriate affective memory, when often we unconsciously suppress an emotion at source through our own involuntary selfcensorship?'28

Of course, Stanislavsky was well aware of memory's subjectivity and fallibility - as he articulated in the famous analogy of searching through a large house with countless rooms and cupboards and drawers for a tiny bead 'that first glinted and then was gone forever'. He advised his actors, 'don't for a moment imagine you can retrieve a feeling that has gone forever. Tomorrow [...] you will remember something else. Don't imagine you can return to yesterday's memory, be content with today's. Learn to accept memories that have come to life afresh. ${ }^{29}$ 
Stanislavski also believed that memories were distilled and purified over time, leaving only the most emotionally potent features; and that time synthesises experiences that have evoked similar feelings so that a memory of a single experience can evoke other memories and associated feelings. 'All these traces of similar experiences and feelings are distilled into a single, wider, deeper memory', he wrote, 'there is nothing superfluous in it, only what is most essential. This is a synthesis of all like feelings' ${ }^{30}$ In this then he drew no distinction between authentic and inauthentic affective memories, acknowledging that most of the feelings we experience are recurrent feelings. Although he welcomed 'first time feelings' when they occur in rare moments during an actor's performance, as they 'intensify the truth of our emotions', he believed that they are only useful in short bursts, as they are unstable and unpredictable. Thus he advised the actor to cultivate the use of 'the repeated, the recurrent feelings which our Emotion Memory prompts. Learn, first and foremost, to use them. They are more accessible to us. ${ }^{, 31}$

Stanislavski's theories were informed by the science of his day, yet indicate an intuitive grasp of physiological and cognitive processes that have since been more fully understood through developments in neuroscience. Rhonda Blair draws on nureoscience to nuance the concept of affective memory by making a distinction between emotions and feelings. She explains that whilst emotions are 'neural or chemical patterns', biological responses that involve a change in the physical body/brain, feelings 'are conscious mental formulations [through which] choice and decision-making come into play. ${ }^{32}$ Furthermore, the neurological processing of memory is determined not so much by neurons themselves as the connections between neurons; every time the brain registers an experience the synapses (transmission of signals between nerve cells) in the brain are changed, and in retrieving memories new proteins have to be made to re-store 
that memory. This means that neural pathways are altered by experience and by subsequent recollections of experiences: 'regardless of the kind of memory, reconsolidation is involved in memory retrieval'. ${ }^{33}$ Here Blair quotes Wilson (1998): 'So memory neither produces something completely new, nor simply reproduces something that already exists. Instead, memory is "literally manufactured" [it] is always an "imaginative reconstruction," a constant variation without a discrete origin., 34 This is directly connected to emotions, as each remembering is also a 'new event' or experience that is reconsolidated in relation to the moment and environment in which it is retrieved and which becomes part of the memory's future remembering. This means that any recollection is never felt in precisely the same way.

On this basis Blair argues that the common understanding in standard actor training of affective memory as the truthful recovery or re-experiencing of a previous emotion needs some qualification. The neuroscientific perspectiveallows the actor to work from the perspective that there is no "objective" authentic self, past or otherwise, to engage but only the self-in-the-now of the rehearsal or performance.' It also points to a conception of character as a series of behaviours, a process rather than a 'discrete entity' and, therefore, reinforces the actor's freedom to think creatively in imagining a role by shifting emphasis from the search to uncover and communicate psychological 'truths' to 'psychoemotional improvisations related to the scene or play' ${ }^{35}$ Blair does not pursue these points further, other than noting that neuroscientific perspectives give credence to later developments of Stanislavski's system: the method of physical actions and active analysis in particular. 
Even in his earlier experiments with the System, Stanislavski was keenly aware that memory makes a biological impression, that it resides not just in the mind but also in the body, and thus that physical actions are 'also an important stimulus to feeling' ${ }^{36}$ This led him to the development of the method of physical actions, and later active analysis. Importantly, the method of physical actions was formulated as a technique through which actors can learn to access emotions as a 'by-product' rather than 'endproduct of an acting technique', as Merlin explains:

If emotion was so elusive, perhaps it could be more effectively stimulated, not through directly assaulting the emotion-centre itself, but indirectly, by provoking the will centre (the body) and coercing the thought centre (the imagination). In other words, if the performer actively did something and imaginatively committed to what he or she was doing, appropriate emotions would arise accordingly. ${ }^{37}$

Carnicke, along with Merlin, prefers the approach of active analysis, which has subtle differences with the method of physical actions, although is often used interchangeably. Whilst the method of physical actions focuses on the development of a logical 'score' of individual actions in a scene, active analysis involves improvising around a play's given circumstances to discover 'the underlying structure of action' - which, in dramatic realism, is related to a character's 'intentional action' and is grounded in 'the character's rhythmic energy and trajectory of desire'. ${ }^{38}$ Similarly, Merlin suggests that active analysis is a more holistic psychophysical approach in which 'the logic of sequence was less important than the experiential discoveries made' ${ }^{39}$

We appear to have moved some distance from postdramatic theatre here but the significance of active analysis is that it opens up Stanislavsky's system to approaches that extend beyond psychological realism and, as Merlin suggests, is 'the most exciting way Stanislavsky's theories can be transported into contemporary theatre practice' ${ }^{40}$ The principle of discovery through improvisation overlaps with contemporary devising 
practices and active analysis is particularly relevant to Wallflower, where affective memories both stimulate and are stimulated by the physical activity of dancing (dancing is employed in a loose sense and is at times manifest as simple rhythmic or repeated movement). Monaghan articulated this process in the following way: 'you get a specific detail, and you're trying to tell a story and you just start doing it - and suddenly it can escalate that feeling of being there'. Here Monaghan intuitively highlights experiential discovery through a form of active analysis; although I prefer to adopt the term 'active experiencing', which Carnicke appropriates from cognitive science research on actor processes by Noice and Noice 'as a twenty-first century synonym for Active Analysis' ${ }^{41}$ This term is more appropriate to a postdramatic context as it shifts emphasis away from the rehearsal of a dramatic text to the performance dimension itself.

Although the goal for the performers in Wallflower is the evocation of memories rather than the generation of emotion specifically, emotion is evoked as an inevitable byproduct of the physical duress of the dancing and the psychological duress of both evoking memories and of collectively, in Monaghan's words, 'live curating' the piece in the duration of its performance. It can be argued that the semi- improvised composition of the performance has the resulting affect that the performers have less control over the memories that are evoked and any corresponding emotions that may surface. 'We go to so many different spaces, I mean broken up, gone mad', Monaghan reflected.

You are using things, memories, experiences that you don't always know how you feel about them until you do them ... you're generating new material constantly and the material just happens to be connected to many, many emotions and memories that you haven't fully comprehended or processed or for some of the performers they'd processed them and didn't want to revisit them but they'd ran out of dances. 
The memories themselves and associated emotions are not primary experiences but their reconstruction during the performance event is. And within Wallflower's performance structure, the use of active experiencing as performance material (arguably) elicits primary emotions more frequently and more visibly than in a dramatic or pre-rehearsed representation, emotions not only connected to memory traces but also to the performance situation itself. It is evident in the ways the performers sometimes inhabit the stage and their own bodies: it is evident through Monaghan's (unconscious?) nervous laugh, which we hear repeatedly, or performer Sonia Hughes's occasional, almost inaudible, mumblings as she appears embarrassed by a memory she is revisiting (such as the dance when she realised she was in love or her inept attempt at tap dancing). These are not 'pre-rehearsed strategies to enhance the 'present-time' illusion of performance' such as Tomlin finds in examples of postdramatic theatre that derivatively appropriate a poetics of failure, ${ }^{42}$ but a representation of memories as they are being neurologically reconstituted. Thus, whereas performed failure as postdramatic style creates a veil of irony that shields performers' natural performance anxieties, the possibility of failure inbuilt into the dramaturgical framework, as it is in Wallflower, opens up the affective experiential dimension of performance more explicitly. Whilst I am not suggesting that the performers and spectators necessarily feel more or more authentically in this performance than in dramatic theatre, I am suggesting that the affective responses of the audience are woven into the fabric of the performance and have a more direct impact on the resulting performance composition and that this can affect the process of recollection itself. In fact, since memories are rooted in affect, one could even go so far as to suggest that audiences responses (however minimal) might also give rise to feelings in the performer that trigger specific memories; as was intimated by Monaghan when he commented: 
You develop small relationships with people, and every time this is a new memory, with a new presence and new people in front of you. There was this guy who laughed once when I put my hands on my knees and smelt my shin pads and he said "I do the same thing'. When you're doing this it's important to know that these are the people you're sharing these memories with ...no matter how much we use memories we're in this now and creating this together.

However, although the inclusion of the audience as a considered element is a recurring aspect of Quarantine's theatre work, such direct participation is rare in Wallflower. This means that it is not primarily the spectators' direct engagement with the performers that helps to shape the resultant form of the performance, but their indirect, even unconscious, energetics and the performers are required to be responsive to that energy in 'curating' (pulling together) the overall composition of the performance.

\section{Experiencing and Flow}

I noted earlier both Lehmann's and Baile's descriptions of postdramatic theatre's affective dimension in terms of energies, affects and intensities rather than performed or projected emotion. Blair does not use such terminology in her examination of the neurological processes of emotion, partly because she focuses on the processes in the brain. Like Blair, Eric Shouse also distinguishes between the unconscious and consciousness in relation to emotion, but with different semantics. Drawing on psychology and philosophy, rather than neuroscience, his model posits feelings and emotions as both conscious formulations of sensation, albeit with subtle differences (emotion being more performative). The term 'affect' on the other hand describes bodily intensities or excitations that are non-conscious and abstract. According to Shouse, 'At any moment hundreds, perhaps thousands of stimuli impinge upon the human body and the body responds by infolding them all at once and registering them as an intensity. Affect is this intensity.' Furthermore, because affect 'is unformed and unstructured it can be transmitted between bodies.' Shouse clarifies that this does not mean that one person takes on another's feelings but, rather, is about the way in which 
bodies 'infold' affective resonances from each other. ${ }^{43}$ Thus Schouse puts emphasis on affect as a physiological process that is not only registered throughout the body but also on and by other bodies.

Although his work is applied to the field of media and cultural studies, Schouse's use of the term 'infolding' has resonance with Fischer Lichte's concept of the 'autopoietic' feedback loop in in live performance. ${ }^{44}$ Similarly, this refers to the transference of energetics between and amongst spectators and performers, which, however subtly and imperceptibly, influence the mood, atmosphere and ultimately the performance of a theatre piece. As Fischer Lichte notes, in conventional dramatic theatre this feedback loop might involve largely internal processes on the spectator's part, or subtle responses, such as changes in breathing, sighing or shuffling, which exceed the economy of affects that are shaped and directed within the fictional cosmos itself. However, since the performative turn, 'The feedback loop as a self-referential, autopoietic system enabling a fundamentally open, unpredictable process emerged as the defining principle of theatrical work.' As part of this shift, which involves the presence of the audience as a principle feature of a performance, the 'functioning of the feedback loop' often becomes visible. ${ }^{45}$

In Wallflower the autopoietic system becomes visible in several ways: the process through which performers' memories are often triggered by the memories or actions of other performers; direct engagement with spectators (as in the example given); the spatial configuration, which dictates that spectators can see each other as well as feel and sense each other's corporeal responses; finally, the positioning of the performers when 'resting' amongst the audience, so there is a confusion between performer and spectator. This means that the energetic ebbs and flows of the performance are, 
arguably, more diffuse than a conventional 'end-on' configuration. A key aspect of theatre's autopoietic feedback loop is that it is not simply a two-way system but multidirectional and rhizomatic, hence its flow of energy is unpredictable, depending 'as much on the actors' ability to mobilize energy at any given point during the performance as on every single audience member's level of responsiveness. ${ }^{46}$

I would argue, that it is in the moments of 'failure' that I described above, where Wallflower's performance structure becomes vulnerable to the theatre's precarious liveness, that the feedback loop is most unpredictable. These moments are sometimes uncomfortable as we watch the performers clumsily perform dances or forget mid-step, or struggle to recall the specific details of a memory. Yet they are also highly charged as we witness their frustrations at not being able to remember exactly, their exhaustion and despair when they are simply coping, negotiating in the moment where to go/what to do next, and relief in moments of recovery, or rescue from another performer or spectator. The affective resonances that we infold from the performers also form into feelings (anxiety, hilarity, embarrassment, empathy) that resonate, in turn, circulating back through the space. As a spectator I become more aware of the here and now of the performance moment, of my own body and the bodies of others also watching the performance. Significantly, these are also the moments when engagements with spectators most often occur. Gregory articulates it as follows:

It's about trying to work with frames to create spaces where you can see the working out, you can see people are going through the process of making choices and sometimes getting them wrong, and that's alright. And I guess ultimately there's something that is then passed on to the audience's experience of it, that I want to present it in such a way that they can work it out as well.

This focus on the process of 'working out' is also a focus on active experiencing within the performance event - before and with the audience who are actively experiencing also. 
Although the emphasis on the "present time" performance and its incorporation within dramaturgical composition is a factor that is often used to distinguish postdramatic from dramatic theatre, it should be emphasised that the 'present time' material dimension of performance was a key consideration also in Stanislavsky's practice. What is often overlooked in reductive accounts that bind his System to a theatre of psychological realism, is that "experience" functions as a primary concept in his system; not just in its use as rehearsal material but also its activation within the performance dimension. Experiencing in Stanislavski's discourse is different to 'active experiencing' as I have appropriated the term here as a form of active analysis. Whilst the latter is a conscious technique (or integration of techniques) used in the rehearsal room, 'experiencing', as Carnicke notes, does not relate to any specific, concrete technique but to 'a creative state that the system can, with luck, foster' ${ }^{47}$ Stephenson argues that in the 'creative state', the actor is 'alive and responsive to whatever is happening on stage $[\ldots]$ in a state of heightened awareness and receptivity' and suggests that its achievement is the ultimate goal of Stanislavsky's system. Where achieved, the resulting performance 'will not be fixed but will develop and evolve, alert and responsive to the differences in the way the actor is thinking and feeling and also to what his or her fellow actors are doing onstage. ${ }^{48}$ We could add to this that the actor in the creative state is responsive to the affective resonances circulating from and amongst the audience also. Although Stanislavski stressed the importance of eliminating self-consciousness in the actor's performance - which inhibits concentration and creates unwelcome 'muscular tension' ${ }^{49}$ he also stressed the importance of remaining self-aware, which he believed is fundamental to the creative state. 'The actor's human emotions, which run parallel to the feelings of the role, must remain alive', he said. He also wrote that 'the things 
around us influence the way we feel. And that happens not only in real life but on the stage, too'. ${ }^{50}$

Carnicke suggests the contemporary analogue of experiencing is Psychologist Mihaly Csikszentmihalyi's concept of 'flow', which refers to a sense of totality experienced by athletes and actors at moments of peak performance in which they are entirely within the moment whilst paradoxically experience a feeling of watching themselves perform. ${ }^{51}$ There is no loss of "self" in flow - which would also suggest a loss of control - but a kind of focused attention where the emotions are harnessed, 'not just contained and channelled, but positive, energized, and aligned with the task at hand' ${ }^{52}$

In dramatic theatre the tasks are directed toward the inner and outer action of the play (to energising the characters' intentional actions and desires). Yet a dramatic theatre performance consists of rehearsed material that is repeated over several performances and, in order to enter a creative state of flow successively, the dramatic actor must be able to accomplish, in each performance, the illusion that the character is experiencing his or her circumstances and feelings in the here and now. In this sense, if we accord with Kirby's model, we might argue that the dramatic actor has a more complex job than Wallflower's performers. But this is a difference of kind not of degree. In Wallflower, the performers are constructing the piece at the same time as attempting to recall memories and filter and digest the thoughts and emotions that recall sometimes evokes, as well as coping with the physical exhaustion of dancing itself. Gregory described it as follows: 'They're composing as they make the piece. They're composing text, they're deciding what's good to follow what, what are the repetitions. They're live 
directing themselves and mise-en-scene; they're deciding where they should be in the space, and pace, and what the relationship with the audience is.'

Monaghan referred to ten simple 'techniques' that the performers used to aid the composition. These included: 'story then dance; only dance; only story; shift (mood or topic); start as far into the story as you can and end it before it finishes'. He added: They weren't like a methodology or anything like that, it was more like if you can remember four of these things in the show, well done. You never felt like you were choosing those techniques, you couldn't. You were highly immersed in remembering live and talking to the people around you. The techniques were a way of trying to curate a show that ... we weren't sure where it was going - because the one thing we couldn't control was if it was going to be good, bad, banal, so what we did have to do was to learn how to get in and out; that simple: get in and out.

Although Gregory also denied the use of a specific methodology in Quarantine's work, other than a 'conversational approach', he did speak about a certain 'technicality' in words that echoed Monaghan's, a technicality that is not explicit or self-reflexively acknowledged in the piece but operates on a semi-conscious level in the organic and apparent spontaneous flow of performers' thoughts and actions and which, like all techniques, must be practiced and assimilated to muscular memory (forming synaptic patterning) in order to operate as such. Monaghan's reflection - of being at the same 'immersed' whilst aware of the responsibility to create an aesthetic experience for the audience - whilst not precisely describing a state of flow, bears on its immanent duality. The techniques he describes (which he also refers to as 'work mechanisms') create the underlying structures within Wallflower's overall framework through which the performers' energetics, and the energetics feeding back from and amongst the audience, are infolded and channelled as they collectively curate the emerging material and which aid them in achieving (when they achieve) a state of creative flow. Whilst I am not suggesting that the adoption of Stanislavsky's System is a precondition for performers to 
experience flow, which can happen intuitively, intuition is elusive and cannot be relied upon to occur - an understanding which shaped Stanislavsky's concept of experiencing. I am suggesting therefore that a practiced, psychophysical technique is necessary to create the conditions that can help performers to generate flow - and that this will bear close correlation to Stanislavsky's techniques. After all his 'enduring pertinence', as Merlin notes, is because he was, 'simply untangling, and as far as possible, systematizing, natural human responses' ${ }^{53}$

Although I have focused so far on the improvisatory elements within Wallflower, the piece also contains pre-rehearsed dances from its growing archive. These dances, which Quarantine refer to as 'the solos', form a structural backbone within the piece and 'are made up of our very poignant memories', as Monaghan put it. For instance, the performance I attended included a solo by Sonia Hughes, which recounted a potentially dangerous visit to the Notting Hill Carnival (during which the crowd she was in escaped a near violent conflict with police) and a more intimate memory attached to unrequited love, whilst part of Monaghan's solo involves a memory of being robbed at knifepoint in a nightclub. This material is notably more dramatic than many of the more banal moments (such as Monaghan dancing in his kitchen), much like what Stanislavsky termed 'events' in dramatic theatre, which occur "when an "impelling action" collides with a "counteraction," producing conflict' ${ }^{54}$ Although not every solo is included in every performance Gregory selects which particular solos are to be performed on the performance day - they are relatively fixed and thus, as Gregory notes, 'like any performance they shift but they don't have quite the fragile quality of the other material'. The potentially reductive affects of repeatedly used memories that I referred to earlier, 
is applicable here. Monaghan discussed this very issue in relation to the solos,

which it is worth quoting at length:

We found that the more we went back to it the more we found it difficult to recover that experience of being in the past; and that kept getting diluted. And then you think "this needs to go somewhere people are watching" and you try to go somewhere... So one technique was always to try and remember something new about that experience or try to find something new, and it does happen ... a moment in the show when I'll say "oh I always thought it was this but I've remembered it was this" and that really elevates the experience of remembering it and you attach yourself, something you've forgotten or remembered wrong - you don't know that but now it feels right, you know. It's not a storage shelf, it's not something you can just pick out, every time you remember a memory you re-imagine it.

Again the use of technique is highlighted - although in this instance to tap into the emotional well of memory traces rather than to harness and channel the present affects of the performance situation. Monaghan's metaphor of attaching and the degree to which the memory 'feels right' is significant, suggesting the need for a psychological or psychophysical hook to access the primary material and/or find a new relationship with the memory in order to activate its 're-imagining'. It is in those moments of 'attachment' when the performers appear to enter a state of flow, when their dances are less hesitant, more accomplished. Yet conversely they appear to be transported by the memories away from the present moment. Certainly in my experience as a spectator there was a notable shift from when performers were simply recalling a memory to when they appeared to be immersed in it. In those instances I was also transported, absorbed in the physical commitment of the performers and their emotional connection to the memory, which infused their dancing with vitality, vicariously experiencing their flow. A similar experience is noted in a rehearsal blog by observer Dani Abulhawa, who put it simply: 'From my distance I really notice the visibility of when the steps of this dance are being remembered, compared with moments when they are being...well, felt. ${ }^{55}$ Abulhawa also describes her own emotional response to Sonia's solo in language that suggests the engendering of empathy: 'the hairs on my arms are stood on end, and 
my eyes are filled with tears. [...] At the end of the solo everyone claps in a way that makes me think we all felt something similar.' In the rehearsal Gregory, she notes, refers to the performance as 'a kind of cathartic shaking off', ${ }^{56}$ using a term that might ordinarily be thought antithetical to postdramatic theatre. In this respect such moments of "high drama" might seem to undermine Wallflower's reality-effects. Yet, far from claiming that the performers actions are non-representational, Gregory's comment about framing reality, quoted earlier, articulates an acknowledgement that the apparatus through which theatre "operates" inevitably involves aesthetic selection and the manipulation of affects.

These more obviously dramatic moments described contrast with the moments of awkwardness referred to earlier as they are accomplished, even virtuosic. Whereas when in a state of flow the performers harness and direct the energy in the room where flow is not felt the energy is more scattered. In these moments the performers' psycho-physicality appeared disjoined as they searched for a focus (attachment) for their imagination, as if groping to find an opening that would transport them inside the memory and activate a sense of flow (with Monaghan literally groping as he repeatedly made a circular movement with his hand before hesitantly trying out dance steps). Nevertheless, I suggest that in these moments where failure haunts the performance, the infolding of affective resonances between bodies in the space is most generative. As Bailes argues, failure does not only manifest as an error or an interruption of a system it can also be recuperative, signalling alternative possibilities. 'Those broken moments, where things are glimpsed on stage that seem to be going badly, foreground a radical potential inherent within the labour of all live performance: that is, theatre's facility as 'live' action to de-compose and re-authenticate before us". 57 
In terms of this performance, then, in its fundamental challenge 'to remember every dance ever danced' it is doomed to ultimately fail, not only because memory is rooted in unconscious affects, inflected with other memories and other 'like feelings', but because its formulation in consciousness is always an imaginative reconstruction in a present affective moment. Yet it is in the reconstitution of memory that we 're-authenticate' it in the present, and through which we reshape our histories and reimagine our futures. Wallflower stages this process of imaginative reconstruction, and in doing so frames living moments of memory in the process of their reconsolidation in the real, a process in which the resonances of the spectators' affective engagement are an active and activating presence.

This is, perhaps, signalled at the end of Wallflower when, in a rare moment of theatricality, we are left with a piece of music playing, a spotlight on the now empty dance floor and a mirror ball slowly spinning, before the music fades out and the lights slowly come up. Here, in Wallflower's final moments the dance floor is symbolically passed to the audience and space is given for our contemplation of the memories and feelings that have been evoked and reconstituted throughout the performance and our experience of the performance - which is already, itself, forming into a memory.

\section{Conclusion}

In this paper I have aimed to demonstrate that a return to Stanislavsky's praxis, nuanced by more recent research in cognitive science, has much to offer in the theorisation of postdramatic theatre and can further illuminate its affective, experiential dimension. Since Stanislavsky's praxis evolved from the desire to elicit ephemeral physiological processes on stage during the moment of performance, and since the incorporation of 
process into the dramaturgy of its performance is a common feature of postdramatic work, then there are insights to be gained from the practices that Stanislavsky initiated, if not from the System as a historical humanist technique. Equally postdramatic theories and strategies associated with the postdramatic - such as a 'poetics of failure' - may have value in the field of the dramatic. If, as Stanislavski's writings claim, an emotionally authentic performance can only be achieved when the actor 'experiences' a role in every performance of it then this means that the actor must be actively experiencing, attuned to the unpredictable affective energetics in theatre's autopoietic system and thus to the potential of failure inherent in all performance. Only then will the actor be able to improvise when accidents and errors occur - as unfailingly they do to recuperate the momentary scattering of energy and re-energise his or her performance: in recuperation, s/he may discover too, new possibilities in the "life" of the character and the playing of the role. Cross-pollination between the institutions of theatre and performance, the dramatic and the postdramatic, can only engender further insights into the affective dimension of theatre events and their experiential processes.

${ }^{1}$ (http://qtine.com/work/wallflower-2/> , accessed 01/09/17. Wallflower premiered at Noorderzon Performing Arts Festival, Groningen, NL on 28 August 2015 and toured in the UK and Europe during 2016-17.

${ }^{2}$ See Bella Merlin, Konstantin Stanislavsky (London: Routledge, 2003), and Sharon Marie Carnicke, Stanislavsky in Focus: An Acting Master for the Twenty-First Century ( $2^{\text {nd }}$ Edition) (London, Routledge, 2009).

${ }^{3}$ Graham Stephenson, 'Stanislavsky and Postmodernism', unpublished MPHIL (University of Birmingham, 2012), accessed 20/06/17, available at http://etheses.bham.ac.uk/3321/1/Stephenson12MPhil.pdf

${ }^{4}$ Yana Meerzon, "'Taming of the impulse": on The Wooster Group's acting techniques and methodologies', Theatre, Dance and Performance Training, Volume 4, No. 3 (2013), p. 381- 
98.

${ }^{5}$ Stephenson, p. 2.

${ }^{6}$ See, for example, Philip Auslander, From Acting to Performance: Essays in modernism and Postmodernism, (London: Routledge, 1997).

${ }^{7}$ Hans-Thies Lehmann, Postdramatic Theatre, (London: Routledge, 2006), p. 21, 22.

${ }^{8}$ Lehmann, p. 155.

${ }^{9}$ Ibid., p. 137, 44.

${ }^{10}$ For example, David Barnett notes that the term postdramatic, 'can imply a reflection on the dramatic without necessarily presenting a complete break', 'When is a Play not a Drama? Two Examples of Postdramatic Theatre Texts', NTQ, Vol. 24, No. 1 (2008), p. 14-23, p. 14. Jen Harvie has similarly acknowledged the 'ambivalent' relationship postdramatic practice has with the dramatic, and that it 'can include representation, rather than hoping to supersede it'. 'Introduction: Contemporary theatre in the making', in Jen Harvie and Andy Lavender, eds., Making Contemporary Theatre: International rehearsal processes, (Manchester: Manchester University Press, 20101), p. 14.

${ }^{11}$ Liz Tomlin, Acts and Apparitions: Discourses on the Real in performance Practice and Theory 1990 2010, (Manchester: Manchester University Press, 2013), p. 55.

12 Ibid., p. 71.

${ }^{13}$ Bruce McConachie, ed., Performance and Cognition: Theatre studies and the cognitive turn, (London: Routledge, 2006), p. viii.

${ }^{14}$ Michael Kirby, 'On acting and Not-Acting', in Philip Zarrilli, Acting (Re) Considered: Theories and Practices, (London: Routledge, 1995).

${ }^{15}$ Ibid., p. 47.

${ }^{16}$ Lehmann, p. 37.

${ }^{17}$ Sarah Jane Bailes, Performance Theatre and the Poetics of Failure: Forced Entertainment, Goat Island, Elevator Repair Service, (Oxon/New York: Routledge, 2011), p. xix.

${ }^{18}$ For example, see Daniel Schulze, Authenticity in Contemporary Theatre and Performance: Make it Real, (London: Bloomsbury Methuen Drama, 2017)

${ }^{19}$ Bailes, p. 56, 2.

${ }^{20}$ Ibid., p. 22, xvii.

21 Tomlin, p. 48.

${ }^{22}$ Ibid.

${ }^{23}$ The cast of Wallflower also includes performers Sonia Hughes, Nic Green, Jo Fong and 'DJ' Greg Akehurst.

${ }^{24}$ Carnicke notes that this binary privileging of the method of physical actions in early Russian interpretations of Stanislavsky's work was ideologically driven, since as a concept it 'encodes Soviet expectations' and 'makes Stanislavsky's career palatable to Marxist materialism'. p. 191.

${ }^{25}$ As Carnicke notes, Strasberg's Method has been heavily criticised as 'an unhealthy invasion of the actor's psyche." Ibid, p. 148.

${ }^{26}$ Bella Merlin, Beyond Stanislavsky: The Psychophysical Approach to Actor Training (London: Nick Hern Books, 2001), p. 16

${ }^{27}$ Ibid., p. 11-2.

${ }^{28}$ Ibid., p. 11

${ }^{29}$ Konstantin Stanislavski, An Actor's Work: A Student's Diary, Trans and Ed, Jean Benedetti, (London: Routledge, 2008), p. 207.

${ }^{30}$ Ibid., p. 206.

${ }^{31}$ Ibid., p. 208.

${ }^{32}$ Rhonda Blair, 'Image and Action: cognitive science and actor-training', in McConachie, p. 176.

${ }^{33}$ Ibid., p. 171, 174.

${ }^{34}$ E.A. Wilson Neural Geographies: Feminism and the Microstructure of Cognition, (New York: Routledge, 1998), p.173, in Blair, p. 174.

${ }^{35}$ Ibid., p. 181.

${ }^{33}$ Merlin, Beyond Stanislavsky, p. 15.

${ }^{36}$ Stanislavski, p. 224.

${ }^{38}$ Carnicke, pp. 196, 191.

${ }^{39}$ Merlin, Konstantin Stanislavsky, p. 34.

${ }^{40}$ Ibid., p. 37.

${ }^{41}$ This research by Noice and Noice is briefly discussed by Carnicke, p.196.

42 Tomlin, p. 72. 
${ }^{43}$ Eric Shouse, 'Feeling, Emotion, Affect.' M/C Journal Volume 8, No. 6 (2005), accessed 16/01/18, available at $\langle$ http://journal.media-culture.org.au/0512/03-shouse.php〉. Accessed

${ }^{44}$ Erika Fischer-Lichte, The Transformative Power of Performance: A new aesthetics, (London: Routledge, 2008), p. 38-9.

${ }^{45}$ Ibid., p. 39, 40.

${ }^{46}$ Ibid., p. 59.

${ }^{47}$ Carnicke, p. 129, 139.

${ }^{48}$ Stephenson, p. 17, 56.

${ }^{49}$ Konstantin Stanislavski, My Life in Art, trans Jean Benedetti, (London: Routledge, 2008), p. 258.

${ }^{50}$ Stanislavski, An Actor's Work, p. 209, 212.

${ }^{51}$ Carnicke, p. 130.

52 Goleman in Carnicke, p. 131.

${ }^{53}$ Merlin, Beyond Stanislavsky, p. 9.

${ }^{54}$ Carnicke, p. 199.

${ }^{55}$ Dani Abulhawa, 'Notes From a Wallflower', 7 August 2015, http://qtine.com/notebook/notes-from-awallflower/> [accessed 15 June 2017]

${ }^{56}$ Ibid.

${ }^{57}$ Bailies, p. 99. 